\title{
Influence of Soil Temperature and Moisture on Eruptive Germination and Viability of Sclerotia of Sclerotinia minor and S. sclerotiorum
}

\author{
M. E. Matheron and M. Porchas, The University of Arizona, Yuma Agricultural Center, Yuma 85364
}

\begin{abstract}
Matheron, M. E., and Porchas, M. 2005. Influence of soil temperature and moisture on eruptive germination and viability of sclerotia of Sclerotinia minor and S. sclerotiorum. Plant Dis. 89:5054.

The effect of soil temperature and moisture on eruptive germination and viability of sclerotia of Sclerotinia minor and S. sclerotiorum in field soil was examined. In two trials at constant temperatures, the proportion of sclerotia of both pathogens that germinated in wet soil $(\geq-0.02 \mathrm{MPa})$ tended to decrease as soil temperature increased from 15 to $40^{\circ} \mathrm{C}$, with no germination of sclerotia of S. minor and S. sclerotiorum detected after 1 and 2 weeks, respectively, at $40^{\circ} \mathrm{C}$. In contrast, after 1 to 4 weeks in dry soil $(\leq-100 \mathrm{MPa})$ at $40^{\circ} \mathrm{C}$, germination of sclerotia of $S$. minor and S. sclerotiorum ranged from 28 to $55 \%$ and 42 to $77 \%$, respectively. In field trials, the germination rate of sclerotia of $S$. minor and S. sclerotiorum after 2 to 8 weeks in irrigated soil on the surface or buried at a depth of $5 \mathrm{~cm}$ was significantly lower than that for sclerotia maintained in dry soil at the same depths. On the other hand, after burial at a depth of $10 \mathrm{~cm}$, germination of sclerotia in irrigated and dry soil did not differ significantly after 2 to 8 weeks for $S$. minor and after 2, 4, and 8 weeks for $S$. sclerotiorum. For both pathogens, germination of sclerotia from 2 to 8 weeks in irrigated soil with a mean temperature of $32^{\circ} \mathrm{C}$ was significantly lower than that for sclerotia in irrigated soil with a mean temperature of $26^{\circ} \mathrm{C}$. In microplot trials conducted in July and August, no sclerotia of $S$. minor and S. sclerotiorum germinated after 2 and 3 weeks, respectively, after recovery from flooded soil with mean soil temperatures ranging from 30 to $33^{\circ} \mathrm{C}$. A flood irrigation is often applied to fields for salt management during July or August in the Yuma lettuce production region. Results from these studies suggest that maintaining this flooding event for 2 to 3 weeks in fields with a history of lettuce drop caused by $S$. minor and $S$. sclerotiorum could significantly reduce the population of viable sclerotia.
\end{abstract}

Additional keywords: sclerotia survival

Sclerotinia minor and S. sclerotiorum are soilborne fungi that can cause lettuce drop, a major disease of lettuce (Lactuca sativa) (3). From December through early March, Sclerotinia drop can cause significant economic losses in lettuce fields in southwestern Arizona. During the same period of time, 80 to $90 \%$ of the total lettuce production in the United States is harvested from the desert southwest production region, which includes southwestern Arizona and southeastern California. In this region, lettuce is grown primarily on raised beds with two rows of plants on each bed spaced $30 \mathrm{~cm}$ apart. After crop harvest, lettuce residue and sclerotia of $S$. minor and $S$. sclerotiorum produced on infected plant tissue typically are incorporated into the soil by disking, followed by planting of crops such as wheat or Sudan grass on nonbedded soil or melons, cotton, corn, or safflower on newly constructed beds.

Corresponding author: M. E. Matheron

E-mail: matheron@ag.arizona.edu

Accepted for publication 29 August 2004.

DOI: 10.1094/PD-89-0050

(C) 2005 The American Phytopathological Society
In recent years, lettuce has become the dominant vegetable crop in southwestern Arizona from initial seeding in September through final harvest in late March. At the same time, the incidence of Sclerotinia drop has increased. The relative efficacy of the fungicides dicloran, iprodione, and vinclozolin for control of Sclerotinia species on lettuce has been documented in earlier research (10-12) as well as by extensive use in the field. A new fungicide, boscalid, has recently received registration for use on lettuce (8). In several field trials conducted in Arizona, the highest reduction of Sclerotinia drop achieved among several different fungicides was about $70 \%$ $(7,8)$. Greater reductions in the incidence of disease will require an integrated disease management approach, with chemical control as one component.

In order to develop an effective integrated disease management program for Sclerotinia drop in desert lettuce production systems, we first need to understand the fate of sclerotia of $S$. minor and $S$. sclerotiorum from the time of their production in diseased lettuce fields until the next lettuce crop is planted one or more years later. At certain times of year, agricultural fields in the desert are subjected to high soil temperatures and very low soil mois- ture. Earlier research documented the effect of temperature and soil moisture on the survival of sclerotia of these pathogens. Adams (2) reported that high soil temperatures $\left(40\right.$ to $50^{\circ} \mathrm{C}$ ) and low soil moisture $(-152$ to $-366 \mathrm{MPa})$ reduced survival of sclerotia of $S$. minor. Imolehin and Grogan (6) found that sclerotia of $S$. minor survived better in dry soil $(-1.5 \mathrm{MPa})$ than in moist soil (-0.033 MPa). Moore (9) demonstrated that sclerotia of $S$. sclerotiorum decayed completely within 24 to 45 days when present in three different types of field soils that were subjected to continuous flooding.

The main objective of our research was to examine the impact of soil temperature and moisture on the ability of sclerotia of $S$. minor and S. sclerotiorum to germinate eruptively. Also of interest was the effect of time in soil and depth in soil on sclerotium germination. The goal of this work was to acquire data to facilitate development of cultural practices that would minimize the population of these overseasoning pathogen propagules in soil.

\section{MATERIALS AND METHODS}

Source of fungi and sclerotia. Initially, sclerotia of $S$. minor and $S$. sclerotiorum were collected from naturally infected lettuce plants at two locations in Yuma County, Arizona. Sclerotia were surfacesterilized by agitation in a $0.5 \%$ solution of $\mathrm{NaClO}$ (1:9 dilution of household bleach) for $3 \mathrm{~min}$, rinsed in sterile distilled water, then plated onto potato dextrose agar (PDA). An actively growing colony arising from a sclerotium of $S$. minor or $S$. sclerotiorum was designated SM or SS, respectively. These two isolates were used to produce sclerotia for all laboratory and field experiments. Substrate for production of sclerotia of $S$. minor was prepared by placing 15 to 20 cubes of potato (Solanum tuberosum) tissue (each $1.0 \mathrm{~cm}^{3}$ ) in a series of $125-\mathrm{ml}$ flasks, which were then autoclaved for $20 \mathrm{~min}$, allowed to cool to room temperature for $24 \mathrm{~h}$, and autoclaved again. After autoclaving, each flask was inoculated with a mycelial disk from an actively growing culture of $S$. minor on PDA. After incubation for 4 weeks at $20^{\circ} \mathrm{C}$ in darkness, mature sclerotia were separated from residual potato tissue by washing the contents of each flask in running water within a soil sieve. Sclerotia were air-dried and stored at room temperature $\left(25^{\circ} \mathrm{C}\right)$ in the laboratory until needed. The substrate for producing sclerotia of S. scle- 
rotiorum was prepared by boiling $5.5 \mathrm{~kg}$ of barley grain in 15 liters of tap water for 90 min. After boiling, the liquid was discarded and $1,000 \mathrm{~cm}^{3}$ of moist grain was placed into a series of 2-liter wide mouth flasks. Flasks were autoclaved for $60 \mathrm{~min}$, allowed to cool to room temperature $\left(25^{\circ} \mathrm{C}\right)$, then autoclaved again $24 \mathrm{~h}$ later. When flasks were cool, the contents of each flask were inoculated with a mycelial disk from an actively growing culture of $S$. sclerotiorum on PDA. After a 6-week incubation period at $20^{\circ} \mathrm{C}$ in darkness, abundant sclerotia had formed. The contents of each container were removed, spread on a clean surface, and air-dried. Sclerotia were collected from the barley seed substrate and stored at room temperature.

Laboratory trials. Soil (7-56-37 sandsilt-clay) was collected from an agricultural field that had not received any moisture from rainfall or irrigation for at least 3 months. This soil was screened through 6.5-mm-mesh hardware cloth to remove large soil clods, then placed into Styrofoam containers $7.5 \mathrm{~cm}$ in diameter and 10 $\mathrm{cm}$ deep, each with three 2.0-mm-diameter drain holes. After 15 sclerotia of $S$. minor or S. sclerotiorum were placed in nylonmesh packets $(3.5 \mathrm{~cm}$ wide $\times 3.5 \mathrm{~cm}$ long), one packet was buried $2.5 \mathrm{~cm}$ below the surface of the dry field soil in each container. Containers with sclerotia and soil were maintained in incubators set at constant temperatures of $15,20,25,30,35$, or $40^{\circ} \mathrm{C}$ for 1 to 4 weeks. At each temperature, the soil in half of the containers remained dry for the duration of each trial, whereas the remaining containers were irrigated with sufficient water to thoroughly wet the soil. Containers with irrigated soil were incubated on trays containing a 1-cm-deep layer of water to maintain moisture in the soil. At 1, 2, 3, and 4 weeks after burial in soil, sclerotia were collected, surface-sterilized with a 2-min wash with agitation in $70 \%$ ethanol followed by a 2 min wash with agitation in a $0.5 \%$ solution of $\mathrm{NaClO}$ (1:9 dilution of household bleach), then plated onto acidified PDA after drying. Acidified PDA, used to suppress bacterial growth, was prepared by adding 6 drops of an $85 \%$ lactic acid solution per $250 \mathrm{ml}$ of PDA after autoclaving and cooling to $50^{\circ} \mathrm{C}$, prior to dispensing in petri dishes. Viability was assessed by the ability of sclerotia to germinate eruptively on the agar and subsequently produce daughter sclerotia. Laboratory experiments were established in a split-split-plot design, with soil temperature as the main plot factor and soil moisture and duration of time in soil as subplot factors. In each of the two runs of this experiment, for each species of Sclerotinia, five replicate containers of soil with sclerotia were prepared for each different combination of soil temperature, soil moisture, and duration of time in soil. This test was performed twice (initiated 17 September 1998 and 30 June 1999).
Field trials 1 to 6. Field trials 1 to 3 were initiated 2 July 1996, 19 June 1997 , and 17 July 1998, respectively, at the University of Arizona Yuma Agricultural Center in a silty clay loam soil (7-56-37 sandsilt-clay) typical of that used for lettuce production in the region. Nylon-mesh packets $(7.5 \mathrm{~cm}$ long $\times 3.8 \mathrm{~cm}$ wide $)$ were each filled with 15 sclerotia of $S$. minor or $S$. sclerotiorum. The land on which these experiments were conducted consisted of raised beds with $92 \mathrm{~cm}$ between bed centers. Sclerotia within the packets were placed either at the soil surface or buried at a depth of 5 or $10 \mathrm{~cm}$ within the furrows between raised beds. Soil within the furrow was either irrigated periodically, by filling the furrow with water, or maintained in a dry state. Field trials 1 and 2 were initially irrigated 2 July 1996 and 19 June 1997, respectively, then every 2 weeks until each trial was terminated 8 weeks later. Field trial 3 was initially irrigated 17 July 1998, then weekly until the trial was terminated after 8 weeks. The focus of this research was on the direct effect of irrigation events on subsequent germination of sclerotia in soil and not the effect of lateral movement of irrigation water into plant beds; therefore, sclerotia were placed in the irrigation furrows and not in the plant beds. Temperature sensors were placed in the irrigated and unirrigated soil at the same depths as the sclerotia to monitor soil temperature. Gypsum blocks were used to monitor soil moisture in irrigated furrows, whereas gravimetric soil moisture determination in conjunction with known soil water release curve data for this soil was used to determine water potential of dry soil. At 2, 4, 6, and 8 weeks after placement in soil, sclerotia were collected, surface-sterilized as described earlier, then plated onto PDA to determine their ability to germinate.

Field trials 4 to 6 were initiated 20 March and 14 and 21 August 2000 at the University of Arizona Yuma Agricultural Center and terminated 8 weeks later. The

Table 1. Analysis of variance table evaluating the effects of soil temperature, soil moisture, time in soil, and their interactions on the viability of sclerotia of Sclerotinia minor and S. sclerotiorum in laboratory experiments

\begin{tabular}{|c|c|c|c|c|c|}
\hline \multirow[b]{3}{*}{ Source $^{x}$} & \multirow[b]{3}{*}{ df $^{\mathbf{y}}$} & \multicolumn{4}{|c|}{$P>F\left(\right.$ viability of sclerotia) ${ }^{w}$} \\
\hline & & \multicolumn{2}{|c|}{ S. minor } & \multicolumn{2}{|c|}{ S. sclerotiorum } \\
\hline & & Trial $1^{\mathrm{z}}$ & Trial $2^{z}$ & Trial 1 & Trial 2 \\
\hline Soil temperature (ST) & 5 & $0.0000 * *$ & $0.0000^{* *}$ & $0.0000 * *$ & $0.0000 * *$ \\
\hline Soil moisture (SM) & 1 & $0.0379^{*}$ & $0.0000 * *$ & $0.0000 * *$ & $0.0000 * *$ \\
\hline Time in soil $(\mathrm{T})$ & 3 & $0.0000^{* *}$ & $0.0000 * *$ & $0.0000 * *$ & $0.0000 * *$ \\
\hline $\mathrm{ST} \times \mathrm{T}$ & 15 & $0.0000^{* *}$ & $0.0000 * *$ & $0.0000 * *$ & $0.0000 * *$ \\
\hline $\mathrm{SM} \times \mathrm{T}$ & 3 & $0.0000^{* *}$ & $0.0001 * *$ & $0.0002 * *$ & $0.0305^{*}$ \\
\hline $\mathrm{ST} \times \mathrm{SM}$ & 5 & $0.0000^{* *}$ & $0.0000 * *$ & $0.0000 * *$ & $0.0000 * *$ \\
\hline $\mathrm{ST} \times \mathrm{SM} \times \mathrm{T}$ & 15 & $0.0000^{* *}$ & $0.0000^{* *}$ & $0.0000 * *$ & $0.1226 \mathrm{~ns}$ \\
\hline
\end{tabular}

${ }^{\text {w }}$ Probability of a greater $F$ (level of significance) shown for each source of variation. Probabilities of less than 0.05 and 0.01 are followed by single and double asterisks, respectively.

${ }^{x}$ Source of variation. Soil temperature included $15,20,25,30,35$, and $40^{\circ} \mathrm{C}$. Soil moisture was wet $(\geq-0.02 \mathrm{MPa})$ or dry $(\leq-100 \mathrm{MPa})$. Time in soil was $1,2,3$, and 4 weeks.

y Degrees of freedom.

z Trials 1 and 2 were initiated 17 September 1998 and 30 June 1999, respectively. protocol for these trials was similar to that described for trials 1 to 3 with the followburied at a depth of $5 \mathrm{~cm}$ was evaluated, irrigation frequency ranged from one to three times per week, and the mean soil werares during trials 4 to 6 were 4 was initially irrigated 20 March 2000 then every week until experiment termination 8 weeks later. Field trials 5 and 6 were initially irrigated 14 and 21 August 2000, then every Monday, Wednesday, and Fri-

Field trials 1 to 6 were established in a split-split-plot design, with soil moisture as the main plot factor and duration of time subplot and depth of sclerotia in soil as cies of Sclerotinia, five replicate packets of sclerotia were placed in soil for each different combination of soil moisture, durain soil.

Field trials 7 to 9. This set of trials was initiated 23 May and 1 and 27 August 2001 to evaluate the impact of soil flooding on eruptive germination and viability of scleteen of S. minor and S. sclerotiorum. Fifplaced within nylon-mesh packets as described for earlier field studies. Four plastic pails, each with a capacity of 19 liters, were buried in soil at the University of serve as microplots. Three packets containing sclerotia of $S$. minor or S. sclerotiorum were skewered on each of five wire flags for each pathogen and placed in each of silty pails, after which was added the tests. The packets skewered on each wire flag were spaced at a soil depth of 0,10 , placed in a fifth pail at the same soil until the soil was saturated. A 2.5-cm-deep layer of water was maintained on the soil sclerotia in irrigated soil at the surface or and $20 \mathrm{~cm}$. Temperature sensors were 
surface for the duration of these trials. At $1,2,3$, and 4 weeks after initiation of soil flooding, sclerotia were removed from one pail, washed in water to remove soil, surface-sterilized as described earlier, then plated onto acidified PDA plates to determine their ability to germinate. Sclerotia of $S$. minor and S. sclerotiorum stored in the laboratory were also plated onto acidified PDA at the beginning and end of each soil flooding trial to assess the level of sclerotia viability without flooding.

Field trials 7 to 9 were established in a split-split-plot design, with species of Sclerotinia as the main factor and duration of time and depth of sclerotia in soil as subplot factors. For each of the three trials, five replicate packets of sclerotia were placed in soil for each different combination of species of Sclerotinia, duration of time, and depth of sclerotia in soil.

Analysis of data. Analysis of variance was performed with the GLM procedure within CoStat statistical software (CoHort Software, Monterey, CA). Data from repeated field trials were combined for analysis when variances of data among trials were homogeneous. Significant differences among main effects and any interactions in each experiment were determined by analysis of variance, and treatment means were separated according to the least significant difference (LSD) test.

\section{RESULTS}

Laboratory trials. The main effects of soil temperature, soil moisture, and time in soil, as well as the interactions of soil temperature $\times$ soil moisture, soil temperature $\times$ time in soil, and soil moisture $\times$ time in soil, on eruptive germination of sclerotia of $S$. minor and S. sclerotiorum were significant in both trials. On the other hand, the interaction of soil temperature $\times$ soil moisture $\times$ time in soil on eruptive germination of sclerotia was significant in both trials for $S$. minor and in one of two trials for $S$. sclerotiorum (Table 1). The proportion of sclerotia of both pathogens that germinated from 1 to 4 weeks in wet soil $(\geq-0.02$ $\mathrm{MPa}$ ) tended to decrease as soil temperature increased from 15 to $40^{\circ} \mathrm{C}$ (Table 2). No sclerotia of $S$. minor and S. sclerotiorum germinated after 1 and 2 weeks, respectively, in wet soil at $40^{\circ} \mathrm{C}$ (Table 2). In contrast, after 1 to 4 weeks in dry soil at $40^{\circ} \mathrm{C}$, germination of sclerotia of $S$. minor and S. sclerotiorum ranged from 28 to $55 \%$ and 42 to $77 \%$, respectively (Table 2). Some fungi, primarily Aspergillus spp. and Mucor spp., often were isolated from sclerotia that failed to germinate after recovery from irrigated field soil.

Field trials 1 to 6. For trials 1 to 3 , all main effects of soil moisture, time in soil, and depth in soil, as well as the interactions of these factors, on eruptive germination of sclerotia of $S$. minor were significant (Table 3). For sclerotia of $S$.

Table 2. Effect of soil temperature and soil moisture on viability of sclerotia of Sclerotinia minor and S. sclerotiorum in laboratory experiments

\begin{tabular}{|c|c|c|c|c|c|c|c|c|}
\hline \multirow{3}{*}{$\begin{array}{l}\text { Temperature } \\
\left({ }^{\circ} \mathrm{C}\right)\end{array}$} & \multicolumn{8}{|c|}{ Percent germination of sclerotia ${ }^{w}$} \\
\hline & \multicolumn{4}{|c|}{ S. minor } & \multicolumn{4}{|c|}{ S. sclerotiorum } \\
\hline & 1 week & 2 weeks & 3 weeks & 4 weeks & 1 week & 2 weeks & 3 weeks & 4 weeks \\
\hline \multicolumn{9}{|l|}{ Wet soil ${ }^{\mathrm{x}}$} \\
\hline 15 & $88 \mathrm{a}^{\mathrm{y}}$ & $70 \mathrm{ab}$ & $64 \mathrm{a}$ & $48 \mathrm{ab}$ & $74 \mathrm{abc}$ & $15 \mathrm{c}$ & $28 \mathrm{bc}$ & $53 \mathrm{bc}$ \\
\hline 20 & $87 \mathrm{a}$ & $61 \mathrm{ab}$ & $63 \mathrm{a}$ & $38 \mathrm{bc}$ & $69 c$ & $15 \mathrm{c}$ & $43 \mathrm{~b}$ & $30 \mathrm{~d}$ \\
\hline 25 & $69 \mathrm{ab}$ & $56 a b c$ & $59 \mathrm{ab}$ & $36 \mathrm{bc}$ & $41 \mathrm{~d}$ & $4 \mathrm{c}$ & $15 \mathrm{~cd}$ & $27 \mathrm{de}$ \\
\hline 30 & $47 \mathrm{~b}$ & $31 \mathrm{~cd}$ & $40 \mathrm{bc}$ & $33 \mathrm{bc}$ & $33 \mathrm{~d}$ & $2 \mathrm{c}$ & $25 \mathrm{c}$ & $28 \mathrm{de}$ \\
\hline 35 & $17 \mathrm{c}$ & $4 \mathrm{de}$ & $1 \mathrm{~d}$ & $0 \mathrm{~d}$ & $27 \mathrm{~d}$ & $0 \mathrm{c}$ & $18 \mathrm{c}$ & 9 ef \\
\hline 40 & $0 \mathrm{c}$ & $0 \mathrm{e}$ & $0 \mathrm{~d}$ & $0 \mathrm{~d}$ & $2 \mathrm{e}$ & $0 \mathrm{c}$ & $0 \mathrm{~d}$ & $0 \mathrm{f}$ \\
\hline \multicolumn{9}{|l|}{ Dry soill ${ }^{\mathrm{Z}}$} \\
\hline 15 & $58 \mathrm{~b}$ & $79 \mathrm{a}$ & $33 \mathrm{c}$ & $42 \mathrm{abc}$ & $89 \mathrm{ab}$ & $43 \mathrm{~b}$ & 89 a & 93 a \\
\hline 20 & $55 \mathrm{~b}$ & $69 \mathrm{ab}$ & $41 \mathrm{bc}$ & $61 \mathrm{a}$ & $87 \mathrm{ab}$ & $43 \mathrm{~b}$ & $88 \mathrm{a}$ & $87 \mathrm{a}$ \\
\hline 25 & $55 \mathrm{~b}$ & $65 \mathrm{ab}$ & $68 \mathrm{a}$ & $60 a$ & $86 \mathrm{abc}$ & $41 \mathrm{~b}$ & 89 a & $86 a$ \\
\hline 30 & $54 \mathrm{~b}$ & $71 \mathrm{ab}$ & $76 \mathrm{a}$ & $60 a$ & $91 \mathrm{a}$ & $51 \mathrm{ab}$ & $85 \mathrm{a}$ & $87 \mathrm{a}$ \\
\hline 35 & $49 \mathrm{~b}$ & $48 \mathrm{bc}$ & $70 \mathrm{a}$ & $34 \mathrm{bc}$ & $72 \mathrm{bc}$ & $14 \mathrm{c}$ & $82 \mathrm{a}$ & $36 \mathrm{~cd}$ \\
\hline 40 & $55 \mathrm{~b}$ & $52 \mathrm{abc}$ & $30 \mathrm{c}$ & $28 \mathrm{c}$ & $77 \mathrm{abc}$ & $64 a$ & $42 \mathrm{~b}$ & $64 \mathrm{~b}$ \\
\hline
\end{tabular}

w Viability was assessed by the ability of sclerotia to germinate eruptively on potato dextrose agar and to subsequently produce daughter sclerotia.

x After initial wetting of soil, containers were placed in incubators on trays containing a 1-cm-deep layer of water to maintain moisture in the soil.

y Values in each column followed by a different letter are significantly different $(P=0.05)$ according to LSD. Five replicate containers of soil with sclerotia were prepared for each different combination of incubation temperature, duration of incubation, soil moisture, and species of Sclerotinia. Each value is the mean percentage of sclerotia that germinated from 10 packets of sclerotia collected from two laboratory trials initiated 17 September 1998 and 30 June 1999. For comparison, the mean percent germination of sclerotia of $S$. minor and $S$. sclerotiorum maintained in the laboratory at $25^{\circ} \mathrm{C}$ and not placed in soil ranged from 84 to $96 \%$.

${ }^{\mathrm{z}}$ Dry soil did not receive any moisture from irrigation or rainfall for at least 3 months before initiation of or during the trials.

Table 3. Analysis of variance table evaluating the effects of soil moisture, time in soil, depth in soil, and their interactions on the viability of sclerotia of Sclerotinia minor and S. sclerotiorum in field trials 1 to 3

\begin{tabular}{|c|c|c|c|c|c|c|c|}
\hline \multirow[b]{3}{*}{ Source $^{x}$} & \multirow[b]{3}{*}{$d f^{y}$} & \multicolumn{6}{|c|}{$P>F$ (viability of sclerotia) $^{w}$} \\
\hline & & \multicolumn{3}{|c|}{ S. minor } & \multicolumn{3}{|c|}{ S. sclerotiorum } \\
\hline & & Trial $1^{z}$ & Trial $2^{z}$ & Trial $3^{z}$ & Trial 1 & Trial 2 & Trial 3 \\
\hline Soil moisture (SM) & 1 & $0.0000 * *$ & $0.0000 * *$ & $0.0000 * *$ & $0.0000 * *$ & $0.0000 * *$ & $0.0000 * *$ \\
\hline Time in soil $(\mathrm{T})$ & 3 & $0.0004 * *$ & $0.0000 * *$ & $0.0000 * *$ & $0.1115 \mathrm{~ns}$ & $0.0000^{* *}$ & $0.0000 * *$ \\
\hline Depth in soil (D) & 2 & $0.0000^{* *}$ & $0.0000^{* *}$ & $0.0000^{* *}$ & $0.0109^{*}$ & $0.0074 * *$ & $0.0000 * *$ \\
\hline $\mathrm{SM} \times \mathrm{T}$ & 3 & $0.0004 * *$ & $0.0000 * *$ & $0.0000 * *$ & $0.1226 \mathrm{~ns}$ & $0.0000^{* *}$ & $0.0000 * *$ \\
\hline $\mathrm{SM} \times \mathrm{D}$ & 2 & $0.0000 * *$ & $0.0000 * *$ & $0.0000 * *$ & $0.0244 *$ & $0.0000^{* *}$ & $0.0000 * *$ \\
\hline $\mathrm{T} \times \mathrm{D}$ & 6 & $0.0116^{*}$ & $0.0004 * *$ & $0.0000^{* *}$ & $0.3751 \mathrm{~ns}$ & $0.1026 \mathrm{~ns}$ & $0.0000 * *$ \\
\hline $\mathrm{SM} \times \mathrm{T} \times \mathrm{D}$ & 6 & $0.0116^{*}$ & $0.0095^{* *}$ & $0.0000 * *$ & $0.4845 \mathrm{~ns}$ & $0.0000^{* *}$ & $0.0000 * *$ \\
\hline
\end{tabular}

${ }^{\text {w }}$ Probability of a greater $F$ (level of significance) shown for each source of variation. Probabilities of less than 0.05 and 0.01 are followed by single and double asterisks, respectively.

${ }^{\mathrm{x}}$ Source of variation. Soil moisture was irrigated $(-0.02$ to $-2.0 \mathrm{MPa})$ or not irrigated ( $\left.\leq-100 \mathrm{MPa}\right)$. Time in soil was 2 , 4 , 6 , and 8 weeks. Depth in soil included 0,5 , and $10 \mathrm{~cm}$.

y Degrees of freedom.

z Trials 1, 2, and 3 were initiated on 2 July 1996, 19 June 1997, and 17 July 1998, respectively, at the University of Arizona Yuma Agricultural Center. 
sclerotiorum, the main effects of soil moisture, depth in soil, and the interaction of soil moisture and depth in soil were significant in all three trials, the effects of time in soil and the interactions of soil moisture $\times$ time in soil, and soil moisture $\times$ time in soil $x$ depth in soil were significant in two of three trials, and the interaction of time in soil $\times$ depth in soil was significant in one of three trials (Table 3). Germination rate of sclerotia of $S$. minor and $S$. sclerotiorum after 2 to 8 weeks in irrigated soil on the surface or buried at a depth of 5 $\mathrm{cm}$ was significantly lower than that for sclerotia maintained in dry soil at the same depths (Table 4). On the other hand, after burial at a depth of $10 \mathrm{~cm}$, germination of sclerotia in irrigated and dry soil did not differ significantly after 2 to 8 weeks for $S$. minor and after 2, 4, and 8 weeks for $S$. sclerotiorum. Germination of sclerotia of both pathogens after $2,4,6$, and 8 weeks in irrigated soil with a mean temperature of $32^{\circ} \mathrm{C}$ (trials 1 to 3 ) was significantly lower than that for sclerotia in soil with a mean temperature of $26^{\circ} \mathrm{C}$ (trials 4 to 6) (Table 5). In irrigated soil with a mean temperature of $31^{\circ} \mathrm{C}$ (range 21 to $61^{\circ} \mathrm{C}$ ), some decomposed sclerotia of $S$. minor and $S$. sclerotiorum were detected after 4 weeks, and decomposition was essentially complete after 6 or more weeks. The dry soil did not receive moisture from irrigation or rainfall for at least 3 months before initiation of or during the trials. For trials 1 to 3 , the means (and ranges) of recorded temperatures at depths of 0,5 , and $10 \mathrm{~cm}$ in irrigated soil were $33^{\circ} \mathrm{C}\left(13\right.$ to $\left.65^{\circ} \mathrm{C}\right)$, $32^{\circ} \mathrm{C}\left(21\right.$ to $\left.51^{\circ} \mathrm{C}\right)$, and $31^{\circ} \mathrm{C}\left(22\right.$ to $\left.41^{\circ} \mathrm{C}\right)$, respectively. For dry soil, the means (and ranges) of recorded temperatures at the same soil depths were $40^{\circ} \mathrm{C}\left(12\right.$ to $\left.70^{\circ} \mathrm{C}\right)$, $38^{\circ} \mathrm{C}$ ( 24 to $\left.51^{\circ} \mathrm{C}\right)$, and $36^{\circ} \mathrm{C}\left(28\right.$ to $\left.45^{\circ} \mathrm{C}\right)$, respectively. The ranges in water potential from 4 to 14 days after an irrigation at depths of 0,5 , and $10 \mathrm{~cm}$ were $\geq-0.02$ to $-2.0 \mathrm{MPa}, \geq-0.02$ to $-0.25 \mathrm{MPa}$, and $\geq-0.02 \mathrm{MPa}$, respectively, whereas the value for dry soil was $\leq-100 \mathrm{MPa}$. For trials 4 to 6 , the means (and ranges) of recorded temperatures at depths of 0 and 5 $\mathrm{cm}$ in irrigated soil were $25^{\circ} \mathrm{C}$ (10 to $\left.44^{\circ} \mathrm{C}\right)$ and $26^{\circ} \mathrm{C}\left(12\right.$ to $\left.35^{\circ} \mathrm{C}\right)$, respectively. Water potential for trials 4 to 6 ranged from $\geq-0.02$ to $-0.04 \mathrm{MPa}$. Several different fungi, primarily Aspergillus spp., $M u$ cor spp., Penicillium spp., and Trichoderma spp., were isolated from sclerotia that failed to germinate after recovery from irrigated field soil.

Field trials 7 to 9. Prior to placement in soil, the mean percent germination of sclerotia of $S$. minor and $S$. sclerotiorum ranged from 84 to $96 \%$. The germination rate for sclerotia of both pathogens after 1 week in continuously flooded soil at depths of 0,10 , and $20 \mathrm{~cm}$ ranged from 0 to $26.7 \%$ (Table 6). The germination rate decreased to a range of 0 to $3.3 \%$ after 2 weeks, and no viable sclerotia were detected after a 3- and 4-week period of soil flooding. Some decomposed sclerotia of $S$. minor and $S$. sclerotiorum were detected after 3 weeks and became more plentiful after 4 weeks in flooded soil. The mean soil temperature at each depth during the three trials ranged from 30 to $33^{\circ} \mathrm{C}$, with hourly values ranging from 17 to $44^{\circ} \mathrm{C}$.

\section{DISCUSSION}

A number of factors have been reported to affect survival of sclerotia of $S$. minor and $S$. sclerotiorum, including temperature $(1,13)$, soil moisture (9), and mycoparasites (5). Our studies revealed that sclerotia of $S$. minor and $S$. sclerotiorum in wet soil $(\geq-0.02 \mathrm{MPa})$ were quite sensitive to a constant soil temperature of $40^{\circ} \mathrm{C}$ and did not germinate after 1 and 2 weeks, respectively, at this temperature. Adams (2) also reported that constant moist soil temperatures of 40 to $50^{\circ} \mathrm{C}$ were very detrimental to the viability of sclerotia of $S$. minor. Furthermore, our studies revealed that germination of sclerotia of both pathogens after 4 weeks at a constant temperature of

Table 4. Effect of soil depth and soil moisture on viability of sclerotia of Sclerotinia minor and S. sclerotiorum in field experiments

\begin{tabular}{|c|c|c|c|c|c|c|c|c|}
\hline \multirow{3}{*}{$\begin{array}{l}\text { Depth in soil } \\
(\mathbf{c m})\end{array}$} & \multicolumn{8}{|c|}{ Percent germination of sclerotia ${ }^{x}$} \\
\hline & \multicolumn{4}{|c|}{ S. minor } & \multicolumn{4}{|c|}{ S. sclerotiorum } \\
\hline & 2 weeks & 4 weeks & 6 weeks & 8 weeks & 2 weeks & 4 weeks & 6 weeks & 8 weeks \\
\hline \multicolumn{9}{|l|}{ Irrigated soily } \\
\hline 0 & $2 b^{z}$ & $2 \mathrm{~b}$ & $3 \mathrm{c}$ & $0 \mathrm{c}$ & $22 \mathrm{~b}$ & $7 \mathrm{c}$ & $9 \mathrm{~b}$ & $0 \mathrm{c}$ \\
\hline 5 & $12 \mathrm{~b}$ & $4 \mathrm{~b}$ & $3 c$ & $0 \mathrm{c}$ & $24 \mathrm{~b}$ & $23 \mathrm{bc}$ & $11 \mathrm{~b}$ & $6 \mathrm{c}$ \\
\hline 10 & $7 \mathrm{~b}$ & $11 \mathrm{~b}$ & $0 \mathrm{c}$ & $11 \mathrm{bc}$ & $21 \mathrm{~b}$ & $28 \mathrm{bc}$ & $11 \mathrm{~b}$ & $6 c$ \\
\hline \multicolumn{9}{|l|}{ Dry soily } \\
\hline 0 & $75 \mathrm{a}$ & $48 \mathrm{a}$ & $56 \mathrm{a}$ & $44 \mathrm{a}$ & $68 \mathrm{a}$ & 66 a & $53 \mathrm{a}$ & $39 a$ \\
\hline 5 & $64 \mathrm{a}$ & $39 \mathrm{a}$ & $35 \mathrm{~b}$ & $22 \mathrm{~b}$ & $65 \mathrm{a}$ & $60 \mathrm{a}$ & $52 \mathrm{a}$ & $34 a b$ \\
\hline 10 & $7 \mathrm{~b}$ & $15 \mathrm{~b}$ & $8 \mathrm{c}$ & $3 \mathrm{c}$ & $50 \mathrm{ab}$ & $45 \mathrm{ab}$ & $35 \mathrm{a}$ & $18 \mathrm{bc}$ \\
\hline
\end{tabular}

$\mathrm{x}$ Viability was assessed by the ability of sclerotia to germinate eruptively on potato dextrose agar and to subsequently produce daughter sclerotia.

${ }^{y}$ Irrigation frequencies among trials ranged from 7 to 14 days. Dry soil did not receive any moisture from irrigation or rainfall for at least 3 months before initiation of or during trials. Ranges in water potential from 4 to 14 days after an irrigation at a depth of 0,5 , and $10 \mathrm{~cm}$ were -0.02 to $-2.0 \mathrm{MPa},-0.02$ to $-0.25 \mathrm{MPa}$, and $-0.02 \mathrm{MPa}$, respectively, whereas the value for dry soil was $\leq-100 \mathrm{MPa}$. Mean recorded temperatures for all three trials at depths of 0,5 , and $10 \mathrm{~cm}$ were 33,32 , and $31^{\circ} \mathrm{C}$, respectively, in irrigated soil and 40,38 , and $36^{\circ} \mathrm{C}$, respectively, in dry soil.

${ }^{\mathrm{z}}$ Values in each column followed by a different letter are significantly different $(P=0.05)$ according to LSD. Each value is the mean percentage of sclerotia that germinated from 15 packets of sclerotia collected from three field trials initiated 2 July 1996, 19 June 1997, and 17 July 1998 . For comparison, the mean percent germination of sclerotia of S. minor and S. sclerotiorum maintained in the laboratory at $25^{\circ} \mathrm{C}$ and not placed in soil ranged from 84 to $96 \%$.

Table 5. Effect of soil temperature on germination of sclerotia of Sclerotinia minor and S. sclerotiorum in irrigated field plots

\begin{tabular}{|c|c|c|c|c|c|c|c|c|}
\hline \multirow{3}{*}{$\begin{array}{l}\text { Mean soil } \\
\text { temperature }\left({ }^{\circ} \mathbf{C}\right)^{\mathrm{y}}\end{array}$} & \multicolumn{8}{|c|}{ Percent germination of sclerotia ${ }^{x}$} \\
\hline & \multicolumn{4}{|c|}{ S. minor } & \multicolumn{4}{|c|}{ S. sclerotiorum } \\
\hline & 2 weeks & 4 weeks & 6 weeks & 8 weeks & 2 weeks & 4 weeks & 6 weeks & 8 weeks \\
\hline 26 & $27 a^{z}$ & $23 \mathrm{a}$ & $23 \mathrm{a}$ & $20 \mathrm{a}$ & $56 \mathrm{a}$ & $54 \mathrm{a}$ & $53 \mathrm{a}$ & $42 \mathrm{a}$ \\
\hline 32 & $7 \mathrm{~b}$ & $3 \mathrm{~b}$ & $3 \mathrm{~b}$ & $0 \mathrm{~b}$ & $23 \mathrm{~b}$ & $15 \mathrm{~b}$ & $10 \mathrm{~b}$ & $3 \mathrm{~b}$ \\
\hline \multicolumn{9}{|c|}{$\begin{array}{l}\text { x Viability was assessed by the ability of sclerotia to germinate eruptively on potato dextrose agar and to subsequently produce daughter sclerotia. } \\
\text { y A mean soil temperature of } 26^{\circ} \mathrm{C} \text { at depths of } 0 \text { and } 5 \mathrm{~cm} \text { was recorded in three field trials initiated } 20 \text { March and } 14 \text { and } 21 \text { August } 2000 \text {; whereas a mean } \\
\text { soil temperature of } 32^{\circ} \mathrm{C} \text { was recorded at the same soil depths in three field trials initiated } 2 \text { July } 1996 \text {, } 19 \text { June 1997, and } 17 \text { July } 1998 \text {. Water potential } \\
\text { values between irrigations ranged from } \geq-0.02 \text { to }-2.0 \mathrm{MPa} \text {. }\end{array}$} \\
\hline \multicolumn{9}{|c|}{$\begin{array}{l}{ }^{\mathrm{z}} \text { Values in each column followed by a different letter are significantly different }(P=0.05) \text { according to LSD. Each value is the mean percentage of sclerotia that } \\
\text { germinated from } 30 \text { packets of sclerotia collected from three field trials at depths of } 0 \text { and } 5 \mathrm{~cm} \text { after } 2,4,6 \text {, and } 8 \text { weeks in irrigated soil. For comparison, the } \\
\text { mean percent germination of sclerotia of } S \text {. minor and } S \text {. sclerotiorum maintained in the laboratory at } 25^{\circ} \mathrm{C} \text { and not placed in soil ranged from } 84 \text { to } 96 \% \text {. }\end{array}$} \\
\hline
\end{tabular}


$35^{\circ} \mathrm{C}$ was significantly reduced compared to that at 15 and $20^{\circ} \mathrm{C}$. In field trials, after 8 weeks in irrigated soil, the proportion of sclerotia that germinated after exposure to mean soil temperatures of 26 and $32^{\circ} \mathrm{C}$ declined from 20 to $0 \%$, respectively, for S. minor and from 42 to $3 \%$, respectively, for $S$. sclerotiorum.

Soil moisture has a significant effect on germination of sclerotia of $S$. minor and $S$. sclerotiorum as well. We observed no germination of sclerotia of either pathogen in wet soil $(\geq-0.02 \mathrm{MPa})$ after 1 and 2 weeks at a constant temperature of $40^{\circ} \mathrm{C}$, whereas germination rates ranged from 28 and $64 \%$ after 4 weeks in dry soil $(\leq-100 \mathrm{MPa})$. In field trials, after 8 weeks on the surface or at a depth of $5 \mathrm{~cm}$, the germination rate of sclerotia of both pathogens ranged from 0 to $6 \%$ in irrigated soil and 22 to $39 \%$ in dry soil. Under conditions of continuous flooding, no sclerotia of $S$. minor or $S$. sclerotiorum germinated in field soil after 2 and 3 weeks, respectively, when hourly temperatures ranged from 17 to $44^{\circ} \mathrm{C}$. Moore (9) reported complete decay of sclerotia of S. sclerotiorum after 24 to 45 days in three different types of flooded soils at temperatures of 22 to $26^{\circ} \mathrm{C}$.

Virtually all sclerotia recovered after 1 to 3 weeks in moist soil or up to 8 weeks in dry soil appeared to be physically intact. It is not known whether the intact sclerotia that failed to germinate on PDA were alive but not capable of germinating on this medium or were truly dead. As pointed out by Grogan (4), if the test for survival involves culturing on a nutrient medium after the recovered sclerotia are washed and surface-sterilized, we know only what portion was capable of hyphal germination in a highly artificial situation. For accurate prediction of disease potential, we need to know the portion of the sclerotia population that is capable of myceliogenic or carpogenic germination under more natural conditions (4). In our studies, on the other hand, when the mean soil temperature ranged from 30 to $33^{\circ} \mathrm{C}$, decay and disintegration of sclerotia of $S$. minor and $S$. sclerotiorum began to be observed after 3 weeks in continuously flooded soil and 4 weeks in soil irrigated every 7 days. Decomposition of sclerotia was essentially complete after 6 or more weeks in soil irrigated every 7 days at this range of soil temperatures. These decayed and disintegrated sclerotia did not germinate on PDA and can be considered dead due to their physical deterioration.

Several fungi, primarily Aspergillus spp., Mucor spp., Penicillium spp., and Trichoderma spp., were isolated from sclerotia that failed to germinate after recovery from irrigated field soil; however, the role of these fungi in decay of sclerotia was not determined. Imolehin and Grogan (6) retrieved Trichoderma spp., Fusarium spp., Chaetophoma spp., Penicillium spp., and Mucor spp. from field sclerotia of S. minor that failed to germinate, with Trichoderma spp. being most numerous and most efficient in parasitizing sclerotia. The role of soil microorganisms in the destruction of sclerotia requires more extensive scrutiny.

We noted a significant decrease in germination of sclerotia of $S$. minor after burial in dry soil at a depth of $10 \mathrm{~cm}$ for 2 to 8 weeks compared to placement at the soil surface. A similar trend, significant only after 8 weeks in dry soil, also was noted for sclerotia of $S$. sclerotiorum. The cause of this decrease in germination is unknown. The soil at these depths was extremely dry ( $\leq-100 \mathrm{MPa})$. The means (and ranges) of soil temperatures recorded hourly at the soil surface and at a depth of $10 \mathrm{~cm}$ were $40^{\circ} \mathrm{C}\left(12\right.$ to $\left.70^{\circ} \mathrm{C}\right)$ and $36^{\circ} \mathrm{C}$ (28 to $45^{\circ} \mathrm{C}$ ), respectively. Although sclerotia at the soil surface were exposed to mean and daily periods of temperatures higher than that of sclerotia at the $10-\mathrm{cm}$ depth, the higher minimum temperature values noted at the $10-\mathrm{cm}$ depth compared

Table 6. Viability of sclerotia of Sclerotinia minor and S. sclerotiorum from flooded field soil microplots

\begin{tabular}{lccccc}
\hline & \multirow{2}{*}{$\begin{array}{c}\text { Depth of } \\
\text { sclerotia in } \\
\text { soil } \mathbf{( c m )}\end{array}$} & \multicolumn{4}{c}{$\begin{array}{c}\text { Percent germination of sclerotia after placement } \\
\text { in flooded field soily }\end{array}$} \\
\cline { 3 - 6 } Pathogen & 0 & $\mathbf{1}$ week $^{\mathbf{z}}$ & $\mathbf{2}$ weeks & 3 weeks & 4 weeks \\
\hline S. minor & $0.7 \mathrm{bc}$ & $0 \mathrm{a}$ & 0 & 0 \\
S. minor & 10 & $0 \mathrm{c}$ & $0 \mathrm{a}$ & 0 & 0 \\
S. minor & 20 & $0 \mathrm{c}$ & $0 \mathrm{a}$ & 0 & 0 \\
S. sclerotiorum & 0 & $26.7 \mathrm{a}$ & $0 \mathrm{a}$ & 0 & 0 \\
S. sclerotiorum & 10 & $12.7 \mathrm{~b}$ & $3.3 \mathrm{a}$ & 0 & 0 \\
S. sclerotiorum & 20 & $9.3 \mathrm{bc}$ & $1.3 \mathrm{a}$ & 0 & 0 \\
$P>F$ & & $0.0000^{* *}$ & $0.0723^{* *}$ & $\ldots$ & $\ldots$ \\
\hline
\end{tabular}

${ }^{y}$ Viability was assessed by the ability of sclerotia to germinate eruptively on potato dextrose agar and to subsequently produce daughter sclerotia. The three runs of this trial were initiated 23 May and 1 and 27 August 2001. The mean soil temperature at each depth during the three runs of this trial ranged from 30 to $33^{\circ} \mathrm{C}$, with hourly values ranging from 17 to $44^{\circ} \mathrm{C}$. Water was added to all microplots until the soil was saturated, then a $2.5-\mathrm{cm}$ layer of water was maintained on the soil surface for the duration of these trials.

${ }^{\mathrm{z}}$ Values in this column followed by a different letter are significantly different $(P \leq 0.05)$ according to LSD. Each value is the mean percentage of sclerotia that germinated from 15 packets of sclerotia. For comparison, the mean percent germination of sclerotia of S. minor and S. sclerotiorum maintained in the laboratory at $25^{\circ} \mathrm{C}$ and not placed in flooded soil ranged from 84 to $96 \%$. to the soil surface might have provided a sustained temperature range which over time affected subsequent germination of sclerotia to a greater extent than shorter daily periods of higher absolute temperatures. Further experiments are needed to substantiate this hypothesis.

Results from the current investigations suggest that flooding fields infested with sclerotia of $S$. minor and S. sclerotiorum for at least 2 and 3 weeks, respectively, with mean soil temperatures in the 30 to $33^{\circ} \mathrm{C}$ range, could significantly reduce the population of viable sclerotia in infested fields. Application of a flood irrigation to fields in July or August for soil salt management is a common cultural practice in the desert southwest lettuce production area, where fields are laser-leveled and can easily be flooded. If this flood irrigation could be maintained for a period of 2 to 3 weeks, then successful control of Sclerotinia drop and effective salt management might be achieved simultaneously.

\section{LITERATURE CITED}

1. Adams, P. B. 1975. Factors affecting survival of Sclerotinia sclerotiorum in soil. Plant Dis. Rep. 59:599-602.

2. Adams, P. B. 1987. Effects of soil temperature, moisture, and depth on survival and activity of Sclerotinia minor, Sclerotium cepivorum, and Sporidesmium sclerotivorum. Plant Dis. 71:170-174.

3. Anonymous. 1985. Integrated pest management for cole crops and lettuce. University of California I.P.M. Project. Publ. 3307.

4. Grogan, R. G. 1979. Sclerotinia species: Summary and comments on needed research. Phytopathology 69:908-910.

5. Huang, H. C. 1977. Importance of Coniothyrium minitans in survival of Sclerotinia sclerotiorum in wilted sunflower. Can. J. Bot 55:289-295.

6. Imolehin, E. D., and Grogan, R. G. 1980 Factors affecting survival of sclerotia, and effects of inoculum density, relative position, and distance of sclerotia from the host on infection of lettuce by Sclerotinia minor. Phytopathology 70:1162-1167.

7. Matheron, M. E., and Matejka, J. C. 1989. In vitro and field comparison of six new fungicides with iprodione and vinclozolin for control of leaf drop of lettuce caused by Sclerotinia sclerotiorum. Plant Dis. 73:727-730.

8. Matheron, M. E., and Porchas, M. 2004. Activity of boscalid, fenhexamid, fluazinam, fludioxonil, and vinclozolin on growth of Sclerotinia minor and $S$. sclerotiorum and development of lettuce drop. Plant Dis. 88:665-668.

9. Moore, W. D. 1949. Flooding as a means of destroying the sclerotia of Sclerotinia sclerotiorum. Phytopathology 39:920-927.

10. Patterson, C. L., and Grogan, R. G. 1985. Differences in epidemiology and control of lettuce drop caused by Sclerotinia minor and $S$. sclerotiorum. Plant Dis. 69:766-770.

11. Reilly, C. C., and Lamoureux, G. L. 1981. The effects of the fungicide iprodione on the mycelium of Sclerotinia sclerotiorum. Phytopathology 71:722-727.

12. Springer, J. K., and Johnston, S. A. 1982 Fungicides for lettuce drop. Plant Dis. 66:281.

13. Van Den Berg, L., and Lenz, C. P. 1968. The effect of relative humidity and temperature on survival and growth of Botrytis cinerea and Sclerotinia sclerotiorum. Can. J. Bot. 46:14771481 . 